\title{
Immunohistochemical characterization of oxidative stress in the lungs of rats exposed to the humidifier disinfectant polyhexamethylene guanidine hydrochloride
}

\author{
Yong-Hoon Lee ${ }^{*}$, Dong-Seok Seo', Mi Ju Lee', and Hyo-Geun Cha' ${ }^{1}$ \\ 1 Pathology Department, Inhalation Toxicity Research Center, Chemicals Research Bureau, Occupational Safety and Health Research \\ Institute, Korea Occupational Safety and Health Agency, 339-30 Expo-ro, Yuseong-gu, Daejeon 34122, Republic of Korea
}

\begin{abstract}
Polyhexamethylene guanidine hydrochloride (PHMG-HCl), an antimicrobial additive in humidifier disinfectants, was associated with the pulmonary disease outbreak in South Korea. However, PHMG-mediated oxidative stress has only been studied in vitro. Here, we evaluated PHMG-induced oxidative stress in the lungs of rats exposed to PHMG-HCl. Male F344 rats were exposed to different concentrations of PHMG-HCl for 13-weeks via whole-body inhalation. Histopathological examination of the exposed rats showed the presence of lung lesions, including alveolar/interstitial fibrosis with inflammatory cell infiltration, bronchioalveolar hyperplasia, bronchiolar/alveolar squamous metaplasia, bronchial/bronchiolar epithelial detachment, and alveolar hemorrhage. Immunohistochemical analysis showed that 4-hydroxynonenal (4-HNE) was expressed in the bronchiolar epithelium, mainly in Clara cells and macrophages of the fibrotic tissue. The number of 4-HNE-positive cells increased significantly in a dose-dependent manner. This is the first in vivo study to report PHMG-induced oxidative stress. Our study provides clues to elucidate the mechanisms underlying PHMGinduced damage in patients affected by humidifier disinfectants. (DOI: 10.1293/tox.2019-0049; J Toxicol Pathol 2019; 32: 311-317)
\end{abstract}

Key words: polyhexamethylene guanidine hydrochloride (PHMG-HCl), humidifier disinfectants, immunohistochemistry, 4-hydroxynonenal (4-HNE), oxidative stress, inhalation toxicity

Polyhexamethylene guanidine hydrochloride (PHMG$\mathrm{HCl}$ ) displays a broad range of activity as an antimicrobial agent and is used worldwide ${ }^{1}$. PHMG has been widely used in humidifier disinfectants, wet wipes, and cleaning products $^{2}$. However, in 2011, an outbreak of pulmonary disease in South Korea led to the death of pregnant women and children and was reported to involve PHMG-containing humidifier disinfectants ${ }^{3}$. Epidemiological study reported that pregnant women $(n=35,16 \%)$ and children below 6-years of age $(n=128,58 \%)$ were the most susceptible patients $(n=163$, $74 \%$ ) among 221 clinically confirmed humidifier disinfectants users; moreover, approximately half of the lung-injured patients ( $n=123$ out of 221) used humidifier disinfectants containing $\mathrm{PHMG}^{4}$. Pulmonary injury was associated with acute interstitial pneumonia and fibrosis ${ }^{5}$. Although the pulmonary damage was reported mainly among users of humidifier disinfectants with PHMG-phosphate (PHMG-P), another derivate of $\mathrm{PHMG}$, PHMG-HCl was also consid-

Received: 7 June 2019, Accepted: 13 July 2019

Published online in J-STAGE: 8 August 2019

*Corresponding author: YH Lee (e-mail: dvmone@kosha.or.kr) (C)2019 The Japanese Society of Toxicologic Pathology

This is an open-access article distributed under the terms of the Creative Commons Attribution Non-Commercial No Derivatives (c) $(9)$ (by-nc-nd) License. (CC-BY-NC-ND 4.0: https:// (C) ${ }_{\text {BY NC ND }}$ creativecommons.org/licenses/by-nc-nd/4.0/). ered to be involved in the outbreak ${ }^{3}$.

Oxidative stress is generated from the imbalance between oxidants and antioxidants, and reactive oxygen species (ROS) cause damage to cells by reacting with cellular biomolecules to form free radicals, accumulation of which has been associated with a large number of diseases ${ }^{6}$. Many studies have reported the toxicity of PHMG-P in oxidative stress. For example, PHMG-P-induced ROS in human alveolar A549 cells, in vitro air-liquid interface (ALI) co-culture model or in mouse macrophage RAW264.7 cells, was reported to cause fibrosis and inflammation via cellular signals, such as cytokines ${ }^{7-9}$. However, these studies were only conducted using in vitro models. Therefore, $\mathrm{PHMG}$-induced oxidative stress needs to be confirmed histologically in vivo. The current study aimed to characterize PHMG-induced oxidative stress in the lungs of rats exposed to PHMG-HCl.

Twenty, male, specific-pathogen-free (SPF) F344 rats, obtained from Japan SLC Inc. (Shizuoka, Japan), were randomly assigned to control $\left(0 \mathrm{mg} / \mathrm{m}^{3}\right)$, low-dose $(0.13 \mathrm{mg} /$ $\left.\mathrm{m}^{3}\right)$, mid-dose $\left(0.40 \mathrm{mg} / \mathrm{m}^{3}\right)$, and high-dose $\left(1.20 \mathrm{mg} / \mathrm{m}^{3}\right)$ groups. The rats were housed in a room with controlled temperature of $22 \pm 3^{\circ} \mathrm{C}$, relative humidity of $50 \pm 20 \%, 12: 12 \mathrm{~h}$ light: dark cycle, and fresh air ventilation (10-15 times per h). UV-irradiated pellet food (Teklad Global 18\% Protein Rodent Diet, Harlan Laboratories, Inc., Indianapolis, IN, USA) and UV-irradiated and filtered tap water were given ad libitum. The animal handling protocol was approved by 
the Institutional Animal Care and Use Committee at Occupational Safety and Health Research Institute.

PHMG-HCl was obtained from Beyond industry Co., LTD. (Shanghai, China) through Ministry of Environment. A whole-body exposure chamber (SIS-20RG, Shibata, Saitama, Japan), with an ultrasonic mist-generator, was used to expose the rats to PHMG-HCl at $0,0.13,0.40$, and 1.20 $\mathrm{mg} / \mathrm{m}^{3}$ for $6 \mathrm{~h} /$ day, 5 days/week for 13 -weeks. The chamber conditions with controlled temperature $\left(21.5-25.4^{\circ} \mathrm{C}\right)$, relative humidity $(35.2-80.3 \%)$, pressure $\left(-78.4-1.5 \mathrm{mmH}_{2} \mathrm{O}\right)$, air ventilation flow (257.9-326.9 L/min) and air ventilation cycle (11.9-15.1 cycle/h), were measured with an environmental controller (ICS-20RG, Shibata, Saitama, Japan). The aerosol particles were collected using personal sampler (Airchek XR 5000, SKC Inc., Eighty Four, PA, USA) with $25 \mathrm{~mm}$-micro glass fiber filters (PALLFLEX Membrane Filters, Pall Co., Port Washington, NY, USA). The distribution of aerosol particle size was measured using a cascade impactor (nanoMOUDI Impactor, MSP Co., Shoreview, MN, USA).

All the rats were euthanized and necropsied after 13-weeks of exposure. Lungs were collected from each animal and fixed in 10\% neutral buffered formalin. Lungs were processed, embedded in paraffin, cut in sections of 3-4 $\mu \mathrm{m}$, and then stained with hematoxylin and eosin (H\&E). The sections were also subjected to Masson's trichrome (MT) staining and immunohistochemistry.

For immunohistochemical analysis, sections were deparaffinized with xylene, hydrated in gradual decrease of alcohol solutions, blocked with $\mathrm{H}_{2} \mathrm{O}_{2}$ for $10 \mathrm{~min}$, and then incubated with universal blocking reagent (Bio Genex, San Ramon, CA, USA) for $10 \mathrm{~min}$ at room temperature. The sections were then incubated with a rabbit polyclonal anti-4-hydroxynonenal (4-HNE) antibody (Abcam, Cambridge, UK, ab46545, 1:200) overnight at $4^{\circ} \mathrm{C}$. Positive reactions were visualized with an avidin-biotin horseradish peroxidase complex and 3,3'-diaminobenzidine tetrahydrochloride (DAB) chromogen using the Real ${ }^{\mathrm{TM}}$ Envison ${ }^{\mathrm{TM}}$ Detection system (Dako, Glostrup, Denmark). Sections were counterstained with Mayer's hematoxylin. The morphometric analysis of immunohistochemistry was conducted using Image $\mathbf{J}$ (National Institutes of Health, Bethesda, MA, USA). A total of 10 fields were randomly selected to count the number of positive cells per unit area $\left(0.25 \mathrm{~mm}^{2}\right)$, and the mean number \pm standard deviation were calculated.

For statistical analysis, data were analyzed with SPSS (ver. 19.0, IBM, Chicago, IL, USA). Levene's test was conducted to analyze the homogeneity of variance, followed by one-way analysis of variance (ANOVA). Post-hoc testing was conducted using the Scheffe or Dunnet T3 test for intergroup comparison. Pearson correlation analysis was also conducted to estimate the relationship between the lung lesion severity and the number of 4-HNE-positive cells.

The chamber conditions was measured as $23.0-23.7^{\circ} \mathrm{C}$ temperature, $42.3-50.9 \%$ relative humidity, $-71.5--67.1$ $\mathrm{mmH}_{2} \mathrm{O}$ pressure, 269.5-270.3 L/min airflow, and 12.44$12.48 \mathrm{cycle} / \mathrm{h}$. The average concentrations of $\mathrm{PHMG}-\mathrm{HCl}$ were $0.14 \pm 0.03,0.41 \pm 0.04$, and $1.18 \pm 0.14 \mathrm{mg} / \mathrm{m}^{3}$ for the low, mid, and high dose groups, respectively. The mass median aerodynamic diameter (MMAD) and geometric standard deviation (GSD) of PHMG-HCl were $0.290 \pm 0.018$ and $1.53 \pm 0.08$, respectively, for the low dose group, 0.346 $\pm 0.033 \mu \mathrm{m}$ and $1.47 \pm 0.03$, respectively, for the mid dose group, $0.365 \pm 0.029 \mu \mathrm{m}$ and $1.53 \pm 0.10$, respectively, for the high dose group.

All the animals survived during the study period. Increased respiratory rate and decreased body weight were observed in the high-dose group (data not shown). Gross lesions showed mottled lung in the mid-dose group and ballooning and red focus of the lung in the high-dose group. Histopathological examination showed alveolar/interstitial fibrosis with inflammatory cell infiltration, bronchioalveolar hyperplasia, bronchiolar/alveolar squamous metaplasia, bronchial/bronchiolar epithelial detachment, bronchial/ bronchiolar/alveolar luminal exudate and alveolar hemorrhage in the lungs of rats in the mid- and high-dose groups. However, abnormal lesions were not observed in the lungs of control and low-dose group rats. The severity of the lung lesions increased in a dose-dependent manner (Table 1 and Fig. 1), and fibrosis was confirmed via MT staining (Fig. 2).

Immunohistochemistry was employed to analyze 4-HNE levels in rats exposed to PHMG-HCl and a strong expression was observed in the cytoplasm of the epithelium of bronchioles in the PHMG-HCl-exposed groups. In particular, 4-HNE was expressed in the cytoplasm of Clara cells

Table 1. Histopathology in the Lungs of Rats Exposed to Polyhexamethylene Guanidine Hydrochloride (PHMG-HCl)

\begin{tabular}{|c|c|c|c|c|c|}
\hline Histopathological findings & Dose $\left(\mathrm{mg} / \mathrm{m}^{3}\right)$ & 0 & 0.13 & 0.40 & 1.20 \\
\hline $\begin{array}{l}\text { - Fibrosis with inflammatory } \\
\text { cell infiltration, alveolar/ } \\
\text { interstitial }\end{array}$ & $\begin{array}{l}\text { Total incidence } \\
\text { 1a } \\
2 \\
3\end{array}$ & $\begin{array}{l}0 \\
0 \\
0 \\
0\end{array}$ & $\begin{array}{l}0 \\
0 \\
0 \\
0\end{array}$ & $\begin{array}{l}5 \\
1 \\
4 \\
0\end{array}$ & $\begin{array}{l}5 \\
0 \\
1 \\
4\end{array}$ \\
\hline $\begin{array}{l}\text { - Hyperplasia, } \\
\text { bronchioalveolar }\end{array}$ & $\begin{array}{l}\text { Total incidence } \\
\qquad \begin{array}{c}1 \\
2 \\
3\end{array}\end{array}$ & $\begin{array}{l}0 \\
0 \\
0 \\
0\end{array}$ & $\begin{array}{l}0 \\
0 \\
0 \\
0\end{array}$ & $\begin{array}{l}5 \\
2 \\
3 \\
0\end{array}$ & $\begin{array}{l}5 \\
0 \\
2 \\
3\end{array}$ \\
\hline $\begin{array}{c}\text { - Squamous metaplasia, } \\
\text { bronchiolar/alveolar }\end{array}$ & $\begin{array}{c}\text { Total incidence } \\
1 \\
2\end{array}$ & $\begin{array}{l}0 \\
0 \\
0\end{array}$ & $\begin{array}{l}0 \\
0 \\
0\end{array}$ & $\begin{array}{l}0 \\
0 \\
0\end{array}$ & $\begin{array}{l}4 \\
1 \\
3\end{array}$ \\
\hline $\begin{array}{l}\text { - Detachment, bronchial/ } \\
\text { bronchiolar epithelium }\end{array}$ & $\begin{array}{l}\text { Total incidence } \\
\qquad \begin{array}{c}1 \\
2 \\
3 \\
4\end{array}\end{array}$ & $\begin{array}{l}0 \\
0 \\
0 \\
0 \\
0\end{array}$ & $\begin{array}{l}0 \\
0 \\
0 \\
0 \\
0\end{array}$ & $\begin{array}{l}5 \\
3 \\
2 \\
0 \\
0\end{array}$ & $\begin{array}{l}5 \\
0 \\
1 \\
2 \\
2\end{array}$ \\
\hline $\begin{array}{l}\text { - Exudate, bronchial/ } \\
\text { bronchiolar/alveolar } \\
\text { luminal }\end{array}$ & $\begin{array}{l}\text { Total incidence } \\
1 \\
2 \\
3\end{array}$ & $\begin{array}{l}0 \\
0 \\
0 \\
0\end{array}$ & $\begin{array}{l}0 \\
0 \\
0 \\
0\end{array}$ & $\begin{array}{l}3 \\
3 \\
0 \\
0\end{array}$ & $\begin{array}{l}5 \\
1 \\
3 \\
1\end{array}$ \\
\hline - Hemorrhage, alveolar & $\begin{array}{l}\text { Total incidence } \\
\qquad \begin{array}{c}1 \\
2 \\
3\end{array}\end{array}$ & $\begin{array}{l}0 \\
0 \\
0 \\
0\end{array}$ & $\begin{array}{l}0 \\
0 \\
0 \\
0\end{array}$ & $\begin{array}{l}0 \\
0 \\
0 \\
0\end{array}$ & $\begin{array}{l}2 \\
1 \\
1 \\
0\end{array}$ \\
\hline
\end{tabular}

aHistopathological score: 1, minimal; 2, mild; 3, moderate; 4, marked. 


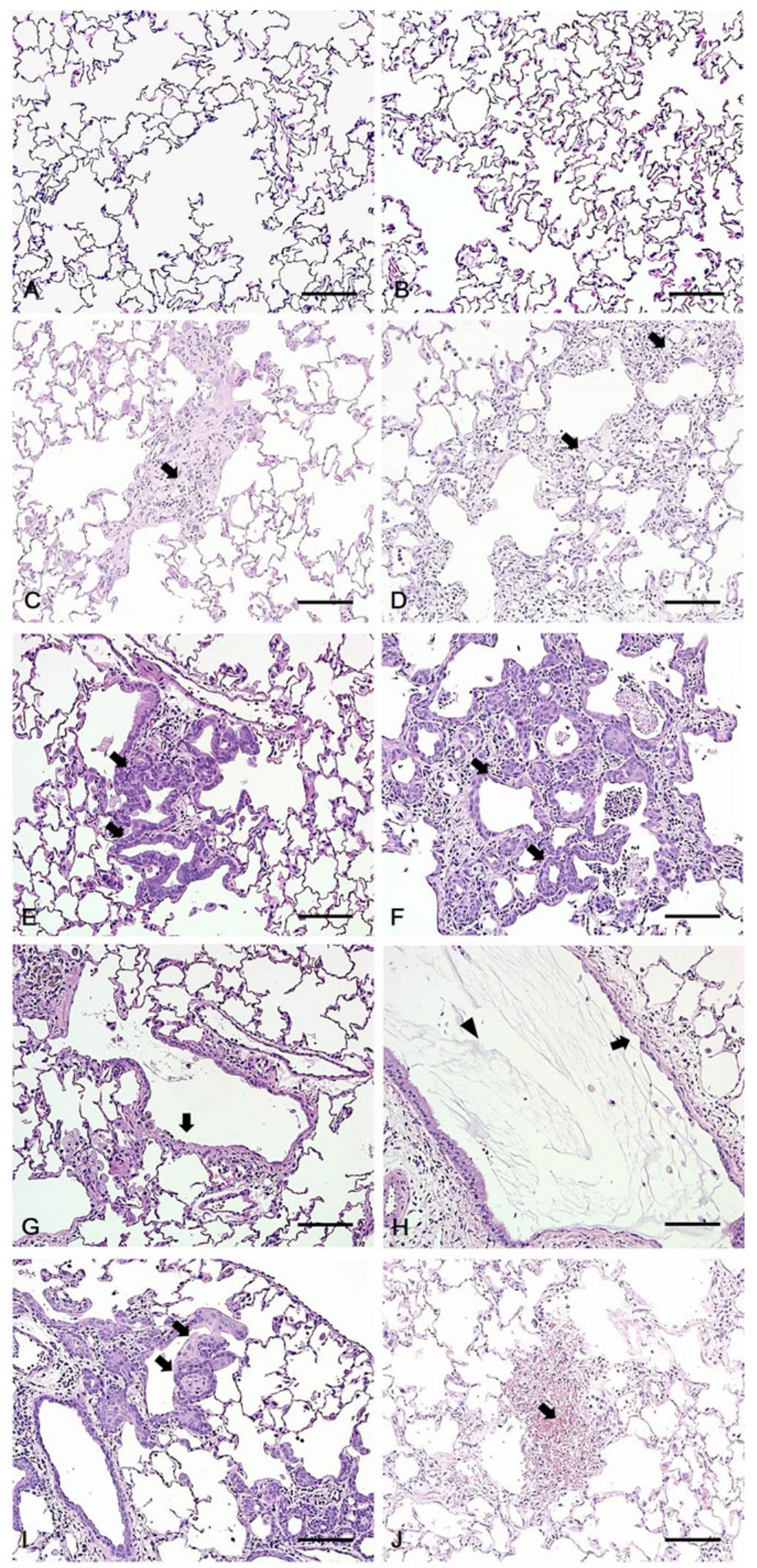

Fig. 1. Histopathology of the lungs of rats exposed to polyhexamethylene guanidine hydrochloride (PHMG-HCl). (A, B) No abnormal lesion was observed in the control and low-dose groups, respectively. (C, D) Fibrosis with inflammatory cell infiltration (arrow) was observed in the alveoli of the mid- and high-dose groups, respectively. (E, F) Hyperplasia of Type II pneumocytes was observed in the alveoli of the mid- and high-dose groups, respectively. (G, H) Epithelial detachment (arrow) and exudate (arrowhead) were observed in the bronchi or bronchiole of the mid- and high-dose groups, respectively. (I) Squamous metaplasia (arrow) was observed in the alveoli and bronchioles of the high-dose groups. (J) Hemorrhage (arrow) was observed in the alveoli of high-dose groups. Bars $=100 \mu$ m, Magnification: $\times 200$, H\&E staining. 

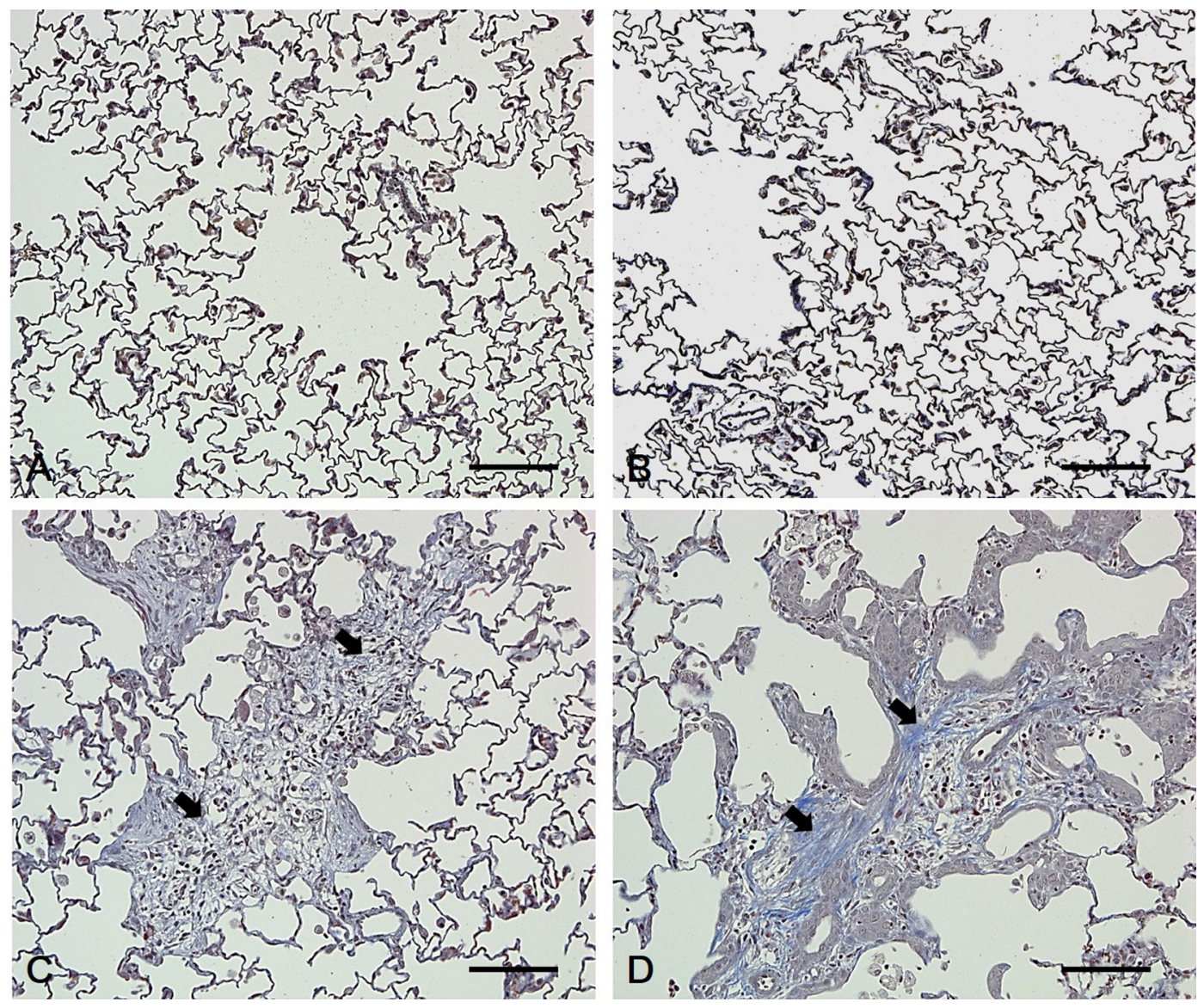

Fig. 2. Characteristics of fibrosis in the lungs of rats exposed to polyhexamethylene guanidine hydrochloride (PHMG-HCl). (A, B) In the control and low-dose groups, no collagen deposition was found in the fibrotic tissues of the lung. (C, D) In the mid-dose and high-dose groups, collagen deposition was observed and stained blue in the lung fibrotic tissues (arrow). Bars $=100 \mu \mathrm{m}$, Magnification: $\times 200$, MT staining.

of the epithelium of bronchioles. Moreover, 4-HNE was expressed in the cytoplasm of macrophages in the fibrotic tissue and the cytoplasm of type II pneumocytes of the alveoli. However, no positive cells were observed in the lungs of the control group rats. In addition, 4-HNE positive cells were mainly detected in the Clara cells in the low-dose groups, whereas in the mid- and high-dose groups, they were mainly found in the macrophages of fibrotic tissues. However, a small number of type II pneumocytes per unit area were found in all the PHMG-HCl-exposed groups (Fig. 3). The number of 4-HNE positive cells significantly increased in a dose-dependent manner (Fig. 4). The number of 4-HNE positive cells also positively correlated with the histopathological score $(\mathrm{r}=0.897, P<0.01)$.

In the present study, pulmonary lesions including alveolar/interstitial fibrosis with inflammatory cell infiltration, bronchioalveolar hyperplasia, bronchiolar/alveolar squamous metaplasia, bronchial/bronchiolar epithelial detachment, and alveolar hemorrhage were observed in histopathology. The severity of the lung lesions significantly increased from mid- to high-dose. This is consistent with the lesions found in PHMG-P inhalation toxicity studies in mice and rats $2,8,10$. Most of the lung lesions in patients injured by humidifier disinfectants were reproduced in the laboratory animal experiments ${ }^{11}$, including fibrosis, which is an irreversible injury to lung and used as the damage criteria in patients that were injured by humidifier disinfectants 3 .

Free radicals mediate lipid peroxidation of polyunsaturated fatty acids, leading to 4-HNE as one of the major final products ${ }^{12}$. This molecule also plays roles in inducing oxidative stress by itself ${ }^{13}$. In addition, 4-HNE has been used as an immunohistochemical marker to evaluate oxidative stress in lungs of smokers and patients who suffer from chronic obstructive pulmonary disease $\mathrm{e}^{14}, 15$. In the current study, 4-HNE showed high levels of expression in the epithelium of bronchioles, mainly Clara cells and macrophages in the fibrotic tissues and type II pneumocytes of the alveoli of the PHMG-HCl-exposed groups in a dose-dependent manner. The mean number of 4-HNE positive cells per group positively correlated with the severity of lung lesions in PHMG$\mathrm{HCl}$-exposed rats. These results suggest that the oxidative stress produced from PHMG-HCl exposure is associated with the increasing severity of the lung lesions in rats.

Clara cells are non-ciliated, non-mucosal secretory cells with a dome-shaped surface that line the pulmonary airway. One of its main functions is to metabolize xenobiot- 


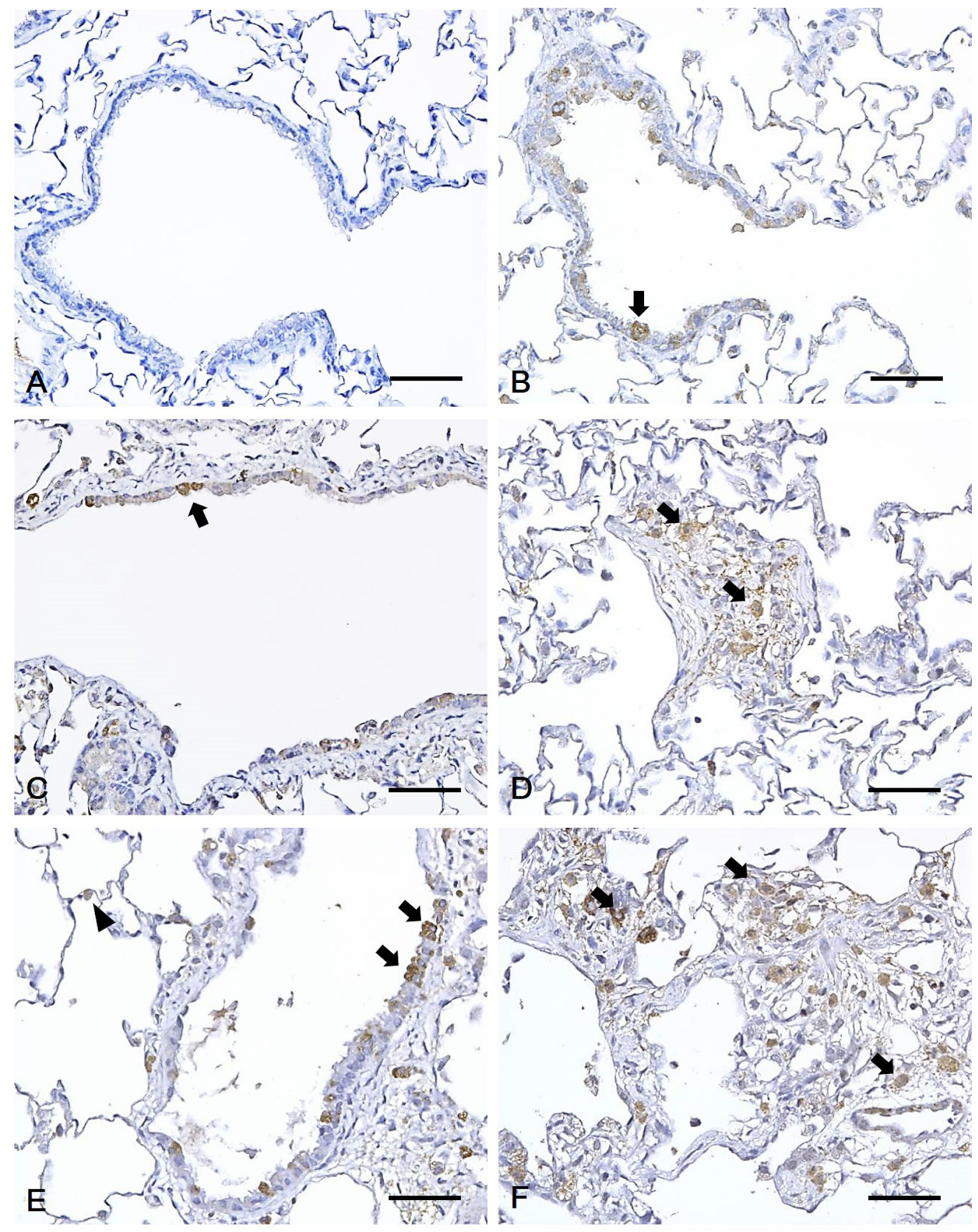

Fig. 3. Immunohistochemical analysis of the lungs of rats exposed to polyhexamethylene guanidine hydrochloride (PHMG-HCl). (A) Control rats showed no 4-hydroxynonenal (4-HNE) positive cells. A positive reaction for 4-HNE was detected in the cytoplasm of Clara cells of bronchiolar epithelium (arrow) in the (B) low-dose, and (C) mid-dose groups. (D) A positive 4-HNE reaction was found in the cytoplasm of macrophages (arrow) of fibrotic tissue in the mid-dose group. (E) Positive 4-HNE reaction was observed in the cytoplasm of Clara cells of bronchiolar epithelium (arrow) and type II pneumocytes (arrowhead) of the alveoli in the high-dose groups. (F) Positive 4-HNE reaction was found in the cytoplasm of macrophages (arrow) of fibrotic tissue in the high-dose group. Bars $=50 \mu \mathrm{m}$, Magnification: $\times 400$.

ics using cytochrome P450 dependent mixed-function oxidases $^{16}$. Cells positive for 4-HNE staining were previously observed in the Clara cells of the epithelium of mice exposed to Dimethylarsinic acid, and these cells were the main target of oxidative stress ${ }^{17}$. These observations suggest that the oxidative stress induced by PHMG-HCl may be due to
ROS generated from cytochrome P450 in Clara cells. The clear relationship between Clara cells and oxidative stress metabolism needs further investigation in the lungs exposed to PHMG-HCl.

The previous study also revealed that the 4-HNE was detected in Type I and II alveolar and bronchial/bronchiolar 


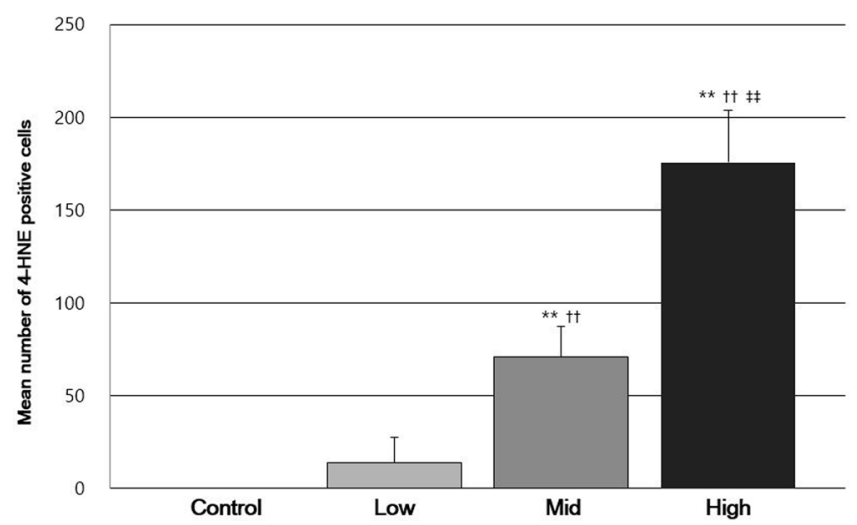

Fig. 4. Comparison of the mean number of 4-hydroxynonenal (4$\mathrm{HNE}$ ) positive cells per unit area among each groups. Significant differences; ${ }^{* *} P<0.01$ compared with the control group; ${ }^{\dagger \dagger} P<0.01$ compared with the low-dose group; $\$ P P<0.01$ compared with the mid-dose group.

epithelium and inflammatory cells, such as macrophages and neutrophils in lungs of patients who suffered from chronic obstructive pulmonary disease, and it plays a critical role in lung inflammation ${ }^{13}$. In addition, ROS is released by activated phagocytes, such as neutrophils and macrophages and non-phagocytic cells, such as epithelial cells ${ }^{18,19}$.

ROS is produced in activated macrophages through the activation of nicotinamide adenine dinucleotide phosphate reduced (NADPH) oxidase in mitochondria, in what is known as "the respiratory burst", because of the transient consumption of oxygen ${ }^{18}$. This process plays a crucial role in the elimination of invading microorganisms ${ }^{20}$. Activated macrophages also recruit fibroblasts and other inflammatory cells and induce fibrogenesis throughout TGF-beta, a major stimulator of fibrogenesis and other cytokines and chemokines ${ }^{21}$. Our observations are consistent with previous reports that 4-HNE positive macrophages are observed in fibrotic tissues.

In conclusion, we detected the oxidative stress marker 4-HNE in the lungs of rats exposed to PHMG-HCl, a humidifier disinfectant, which suggests that oxidative stress could cause tissue injury and inflammation leading to lung fibrosis. This is the first study to immunohistochemically characterize PHMG-induced oxidative stress in the lungs of rats exposed to PHMG-HCl. Our study to localize PHMGinduced oxidative stress might help elucidate the mechanism of PHMG-induced damage in the lungs of patients injured by humidifier disinfectants.

Disclosure of Potential Conflict of Interest: The authors declare that there are no conflicts of interest in connection with this paper.

Acknowledgments: This research was supported by the Korea Occupational Safety and Health Agency, Ministry of Labor, Republic of Korea, and a Grant-in-Aid for chemical hazard assessment, 2018.

\section{References}

1. Asiedu-Gyekye IJ, Mahmood SA, Awortwe C, and Nyarko AK. A preliminary safety evaluation of polyhexamethylene guanidine hydrochloride. Int J Toxicol. 33: 523-531. 2014. [Medline] [CrossRef]

2. Song JA, Park HJ, Yang MJ, Jung KJ, Yang HS, Song CW, and Lee K. Polyhexamethyleneguanidine phosphate induces severe lung inflammation, fibrosis, and thymic atrophy. Food Chem Toxicol. 69: 267-275. 2014. [Medline] [CrossRef]

3. Park DU, Ryu SH, Lim HK, Kim SK, Choi YY, Ahn JJ, Lee E, Hong SB, Do KH, Cho JL, Bae MJ, Shin DC, Paek DM, and Hong SJ. Types of household humidifier disinfectant and associated risk of lung injury (HDLI) in South Korea. Sci Total Environ. 596-597: 53-60. 2017. [Medline] [CrossRef]

4. Committee on the Investigation of Lung Damage. Korea Centers for Disease Control and Prevention, Ministry of Health and Welfare, White book on health damage outbreak by humidifier disinfectants. Hanrimwon, Seoul, 2014. (In Korean).

5. Lee JH, Kim YH, and Kwon JH. Fatal misuse of humidifier disinfectants in Korea: importance of screening risk assessment and implications for management of chemicals in consumer products. Environ Sci Technol. 46: 2498-2500. 2012. [Medline] [CrossRef]

6. Evans MD, and Cooke MS. Factors contributing to the outcome of oxidative damage to nucleic acids. BioEssays. 26: 533-542. 2004. [Medline] [CrossRef]

7. Jung HN, Zerin T, Podder B, Song HY, and Kim YS. Cytotoxicity and gene expression profiling of polyhexamethylene guanidine hydrochloride in human alveolar A549 cells. Toxicol In Vitro. 28: 684-692. 2014. [Medline] [CrossRef]

8. Kim HR, Lee K, Park CW, Song JA, Shin DY, Park YJ, and Chung KH. Polyhexamethylene guanidine phosphate aerosol particles induce pulmonary inflammatory and fibrotic responses. Arch Toxicol. 90: 617-632. 2016. [Medline] [CrossRef]

9. Kim HR, Shin DY, and Chung KH. The role of NF- $\mathrm{KB}$ signaling pathway in polyhexamethylene guanidine phosphate induced inflammatory response in mouse macrophage RAW264.7 cells. Toxicol Lett. 233: 148-155. 2015. [Medline] [CrossRef]

10. Lee SJ, Park JH, Lee JY, Jeong YJ, Song JA, Lee K, and Kim DJ. Establishment of a mouse model for pulmonary inflammation and fibrosis by intratracheal instillation of polyhexamethyleneguanidine phosphate. J Toxicol Pathol. 29: 95-102. 2016. [Medline] [CrossRef]

11. Huh JW, Hong SB, Do KH, Koo HJ, Jang SJ, Lee MS, Paek D, Park DU, Lim CM, and Koh Y. Inhalation lung injury associated with humidifier disinfectants in adults. J Korean Med Sci. 31: 1857-1862. 2016. [Medline] [CrossRef]

12. Riahi Y, Cohen G, Shamni O, and Sasson S. Signaling and cytotoxic functions of 4-hydroxyalkenals. Am J Physiol Endocrinol Metab. 299: E879-E886. 2010. [Medline] [CrossRef]

13. Awasthi YC, Yang Y, Tiwari NK, Patrick B, Sharma A, Li J, and Awasthi S. Regulation of 4-hydroxynonenal-mediated signaling by glutathione S-transferases. Free Radic Biol Med. 37: 607-619. 2004. [Medline] [CrossRef] 
14. Rahman I, van Schadewijk AA, Crowther AJ, Hiemstra PS, Stolk J, MacNee W, and De Boer WI. 4-Hydroxy-2-nonenal, a specific lipid peroxidation product, is elevated in lungs of patients with chronic obstructive pulmonary disease. Am J Respir Crit Care Med. 166: 490-495. 2002. [Medline] [CrossRef]

15. Goven D, Boutten A, Leçon-Malas V, Marchal-Sommé J, Soler P, Boczkowski J, and Bonay M. Induction of heme oxygenase-1, biliverdin reductase and $\mathrm{H}$-ferritin in lung macrophage in smokers with primary spontaneous pneumothorax: role of HIF-lalpha. PLoS One. 5: e10886. 2010; [CrossRef]. [Medline]

16. Harkema JR, Nikula KJ, and Haschek WM. Respiratory system. In: Haschek and Rousseaux's Handbook of Toxicologic Pathology, vol III, 3rd ed., WM Haschek, CG Rousseaux, and MA Wallig (eds). Academic Press, San Diego. 1935-2000. 2013.

17. An Y, Kato K, Nakano M, Otsu H, Okada S, and Yamanaka
K. Specific induction of oxidative stress in terminal bronchiolar Clara cells during dimethylarsenic-induced lung tumor promoting process in mice. Cancer Lett. 230: 57-64. 2005. [Medline] [CrossRef]

18. Forman HJ, and Torres M. Reactive oxygen species and cell signaling: respiratory burst in macrophage signaling. Am J Respir Crit Care Med. 166: S4-S8. 2002. [Medline] [CrossRef]

19. Thannickal VJ, and Fanburg BL. Reactive oxygen species in cell signaling. Am J Physiol Lung Cell Mol Physiol. 279: L1005-L1028. 2000. [Medline] [CrossRef]

20. Franchini AM, Hunt D, Melendez JA, and Drake JR. Fc $\gamma$ Rdriven release of IL- 6 by macrophages requires NOX2dependent production of reactive oxygen species. J Biol Chem. 288: 25098-25108. 2013. [Medline] [CrossRef]

21. Wynn TA, and Barron L. Macrophages: master regulators of inflammation and fibrosis. Semin Liver Dis. 30: 245-257. 2010. [Medline] [CrossRef] 